\title{
Vérlemezke-mikro-RNS-ek expressziójának változása thrombocytaaktivációval járó betegségekben
}

\author{
Fejes Zsolt - Szilágyi Bernadett - Kappelmayer János dr. - ifj. Nagy Béla dr. \\ Debreceni Egyetem, Általános Orvostudományi Kar, Laboratóriumi Medicina Intézet, Debrecen
}

\begin{abstract}
A mikro-RNS-ek (miRNS) rövid, általában 18-25 nukleotid hosszúságú, nem kódoló RNS-molekulák, melyek kulcsfontosságú szerepet játszanak a sejtek fiziológiás múködéséhez szülkséges gének expressziójának poszttranszkripciós szabályozásában. Fő funkciójuk a messenger RNS-ek (hírvivő RNS, mRNS) múködésének modulálása azáltal, hogy az mRNS 3' UTR-régiójához kötődnek, aminek eredményeként az mRNS által kódolt fehérje kifejeződése gátlódik, de akár az mRNS degradációja is bekövetkezhet. A miRNS-ek nemcsak maggal rendelkező sejtekben, de a vérlemezkékben, a vörösvértestekben, illetve keringő formában a vérben, a vizeletben és egyéb testfolyadékokban is megtalálhatók. Sokan sokáig kételkedve fogadták, hogy a sejtmaggal nem rendelkező keringő „sejtdarabok” a 8-12 napos átlagélettartamukkal hordozhatnak-e funkcionális RNS-molekulákat, és ezáltal képesek lehetnek-e akár fehérjeszintézisre különböző stimulusok hatására. Az elmúlt néhány évben számos közlemény jelent meg, amely bizonyította bizonyos vérlemezke-mRNS-ek és az azok múködését reguláló miRNS-ek sejtaktivációt szabályozó szerepét olyan betegségekben is, melyekben a thrombocyták fokozott aktivációs állapotba kerülnek, például 2-es típusú diabetes mellitusban vagy szeptikus állapotban. Patofiziológiai szerepük mellett a miRNS-ek új biomarkerek is lehetnek ezen betegségek vizsgálatában vagy differenciáldiagnosztikájában. A jelen összefoglaló közlemény a thrombocyta-miRNS-ekról eddig ismeretes adatokat kívánta összegyüjteni, különös tekintettel a diabetesben és szepszisben leírt eltéréseivel.
\end{abstract}

Orv Hetil. 2018; 159(47): 1962-1970.

Kulcsszavak: mikro-RNS, vérlemezke, diabetes mellitus, szepszis, biomarker

\section{Alteration in the expression of platelet microRNAs in diseases with abnormal platelet activation}

\begin{abstract}
MicroRNAs (miRNA) are short, non-coding RNAs consisting of 18-25 nucleotides that regulate posttranscriptionally the gene expression involved in the regulation of physiological processes of the cells. Their key role is to modulate the translation of target mRNAs via binding to complementary sequences within the 3' UTRs of mRNAs resulting in altered protein synthesis or even the degradation of mRNAs. miRNAs are carried not only by cells with nucleus, but also in platelets, red blood cells, and they are present in the circulation, in urine and in other body fluids as well. The fact about functional miRNAs in platelets without nucleus having a half-life of 8-12 days was questioned for a long time, thus it was also obscure whether platelets are able to produce proteins de novo when being exposed to different challenges. In the last few years, several publications have described the expression and function of certain platelet mRNAs with their regulatory miRNAs in terms of regulation of cell activation, especially in diseases in which platelet activation status is elevated, such as in type 2 diabetes mellitus or in sepsis. Apart from their pathophysiological role, miRNAs may be applied as potential new biomarkers in the investigation or differential diagnosis of these clinical conditions. This review article sought to summarize the recent findings about platelet miRNAs focusing on their altered expression in diabetes and sepsis.
\end{abstract}

Keywords: microRNA, platelets, diabetes mellitus, sepsis, biomarker

Fejes Zs, Szilágyi B, Kappelmayer J, Nagy B Jr. [Alteration in the expression of platelet microRNAs in diseases with abnormal platelet activation]. Orv Hetil. 2018; 159(47): 1962-1970.

(Beérkezett: 2018. június 11.; elfogadva: 2018. augusztus 9.)

Semmelweis Ignác születésének 200. évfordulója évében a Szerkesztőség felkérésére készített tanulmány. 


\section{Rövidítések}

ADAM9 = disintegrin and metalloproteinase domain-containing protein 9; CCL4 = cytokines/chemokines chemokine $\mathrm{C}-\mathrm{C}$ motif ligand $4 ; \mathrm{CSFl}=$ colony stimulating factor $\mathrm{l}$; DGCR8 = DiGeorge syndrome critical/chromosomal region $8 ; \mathrm{DIC}=$ disszeminált intravascularis koaguláció; $\mathrm{HDL}=($ high density lipoprotein) magas sưrüségű lipoprotein; ICAMI = (intracellular adhesion molecule-1) intracelluláris adhéziós molekula-1; IL1 $\beta$ = interleukin-1-béta; KLHL5 = Kelch-like protein $5 ; \mathrm{LBP}=$ (lipoprotein-binding protein) lipoproteinkötő fehérje; LPS = (lipopolysaccharide) lipopoliszacharid; miRNS $=$ mikro-RNS; mRNS $=$ (messenger RNS) hírvivó RNS; NF- $\kappa \mathrm{B}=$ nukleárisfaktor-kappa-B; PAIl = (plasminogen activator inhibitor-1) plazminogénaktivátorgátló-1; PGN = (peptidoglycane) peptidoglikán; pre-miRNS $=$ prekurzor miRNS; pri-miRNS = elsődleges miRNS; RISC $=($ RNA-induced silencing complex) RNS által indukált csendesítő komplex; RNS $=$ ribonukleinsav; SELP $=$ P-selectin $;$ TLR $=($ Toll-like receptor) Toll-szerü receptor; $\mathrm{TNF}=$ tumornekrózis-faktor; $\mathrm{TNF} \alpha=$ tumornekrózisfaktor-alfa; TRAP $=($ thrombin receptor activating peptide) trombinreceptor-aktiváló peptid; TRBP = transactivation-responsive RNA-binding protein; UTR = (untranslated region) nem transzlálódó régió; VAMP8 $=$ vesicleassociated microtubule protein 8 ; vWF $=$ von Willebrand-faktor

A mikro-RNS-ek (miRNS, miR) rövid, általában 18-25 nukleotid hosszúságú, nem kódoló RNS-molekulák, melyek kulcsfontosságú szerepet játszanak a sejtek fiziológiás múködéséhez (például differenciáció, proliferáció, sejthalál stb.) szükséges gének expressziójának finomszabályozásában poszttranszkripciós szinten [1]. Eddig több mint 3500 humán miRNS-t azonosítottak, melyek a gének körülbelül $60 \%$-át befolyásolják. Fő feladatuk az mRNS-ek (messenger RNS) funkciójának modulálása a citoplazmában azáltal, hogy a cél-mRNS 3' nem kódoló UTR-régiójához kötődnek [1]. A komplementaritás mértékétôl függő́n az mRNS által kódolt fehérje kifejeződése így gátlódik, de akár az mRNS degradációja is bekövetkezhet. Egy mRNS múködését akár több tucat miRNS szabályozhatja, illetve egy miRNS akár több száz mRNS-t regulálhat. A miRNS-ek a különböző szövetekben egyedi módon, eltérő mértékben expresszálódnak, és megváltozott expressziójuk számos betegség kialakulásához járulhat hozzá, így szív- és érrendszeri, daganatos, valamint autoimmun kórképekben $[1,2]$.

A miRNS-ek a sejtmagban miRNS-génekröl, -intronokról, illetve -exonokról íródnak át az RNS-polimeráz II által, aminek eredményeként elsődleges miRNS-ek (pri-miRNS) keletkeznek (1. ábra). A Drosha és a DGCR8 (DiGeorge syndrome critical/chromosomal region 8) ribonukleáz aktivitásának hatására a pri-miRNS-ek hasítása által kettős láncú prekurzor miRNS-ek (pre-miRNS) keletkeznek, amelyekre úgynevezett „hajtü” (stem loop) konformáció jellemző. A pre-miRNS-ek az Exportin-5 fehérje segítségével kijutnak a sejtmagból a citoplazmába, ahol egy endoribonukleáz, a Dicer alakítja őket tovább, és így alakulnak ki az érett miRNS-ek.
Számos pre-miRNS-nek két, az 5' és a 3' véghez közeli hasítási helye van (például miR-126-5p és miR-126-3p). A citoplazmában a TRBP (transactivation-responsive RNA-binding protein), a Dicer és az Ago2 (Argonaute-2) proteinek alkotják a helikázaktivitással bíró RISCet (RNA-induced silencing complex), amelynek múködésével létrejönnek, illetve stabilizálódnak az egyszálú, funkcionális miRNS-ek $[1,2]$ (1. ábra).

A miRNS-ek nemcsak maggal rendelkező sejtekben, de a vérlemezkékben, a vörösvértestekben, illetve keringô formában a vérben, az anyatejben, a vizeletben és egyéb testfolyadékokban is megtalálhatók [3]. A miRNS-ek sejtnekrózis vagy apoptózis során, illetve aktív szekréció révén vesiculákba csomagolva kikerülhetnek a sejtekből, valamint szabad formában (lipo)proteinekhez kötötten szállítódnak tovább [4] (1. ábra). Egy jelentôs részük (mintegy a $70 \%$-uk) a thrombocytákból szabadul ki, és bejutva más sejtekbe képesek akár azok múködését is befolyásolni [5]. Patofiziológiai szerepük mellett, rendkívüli stabilitásuk miatt, szérumból vagy plazmából mérve a miRNS-ek alkalmas biomarkerek lehetnek számos kórkép, így a fokozott vérlemezke-aktivációval járó betegségek vizsgálatában vagy differenciáldiagnosztikájában, bár egyelőre nem váltak a rutin-labordiagnosztika részévé [6].

\section{A vérlemezke-miRNS-ek funkciója és szabályozása}

\section{A thrombocytaaktiváció fontossága}

A thrombocyták körülbelül 2-5 um nagyságú, sejtmaggal nem rendelkező alakos elemei a vérnek, amelyek fontos szerepet töltenek be az érrendszer integritásának fenntartásában [7]. Nyugalmi állapotban keringenek, amíg az érfalsérülés miatt szabaddá váló subendothelialis kollagén és von Willebrand-faktor (vWF) által aktiválódnak, majd kitapadnak a sérült érfalhoz, aggregálódnak egymással, ezáltal megakadályozva a nagyobb mennyiségû vérvesztést [7]. Ezen túlmenően számos egyéb fiziológiás szerepet betöltenek, úgymint összehangolják a gyulladásos folyamatok lezajlását különböző mediátorok felszabadításával, interakcióba lépnek az immunsejtekkel, továbbá képesek bizonyos kórokozókat (például baktérium, vírus) megkötni, akár „bekebelezni”, vagy az általuk szekretált citokinek által részt venni azok eliminálásában [8]. Számos betegségben ugyanakkor a thrombocyták fokozott aktivációs állapotba kerülnek, ha tartósan fennálló stimulus éri ôket, úgymint a hyperglycaemia 2-es típusú diabetes mellitusban [9], magas koleszterinszint lipidanyagcsere-betegségekben [10] vagy Gramnegatív-baktérium-eredetú lipopoliszacharidok (LPS) súlyos infekció esetén, szeptikus állapotban [11]. Az emelkedett vérlemezke-aktiváció általában magas felszíni és szolúbilis P-selectin (CD62P)-expresszióval jár együtt, mindez vascularis, gyulladásos, illetve thromboticus szövődmények kialakulásához vezethet [12]. 

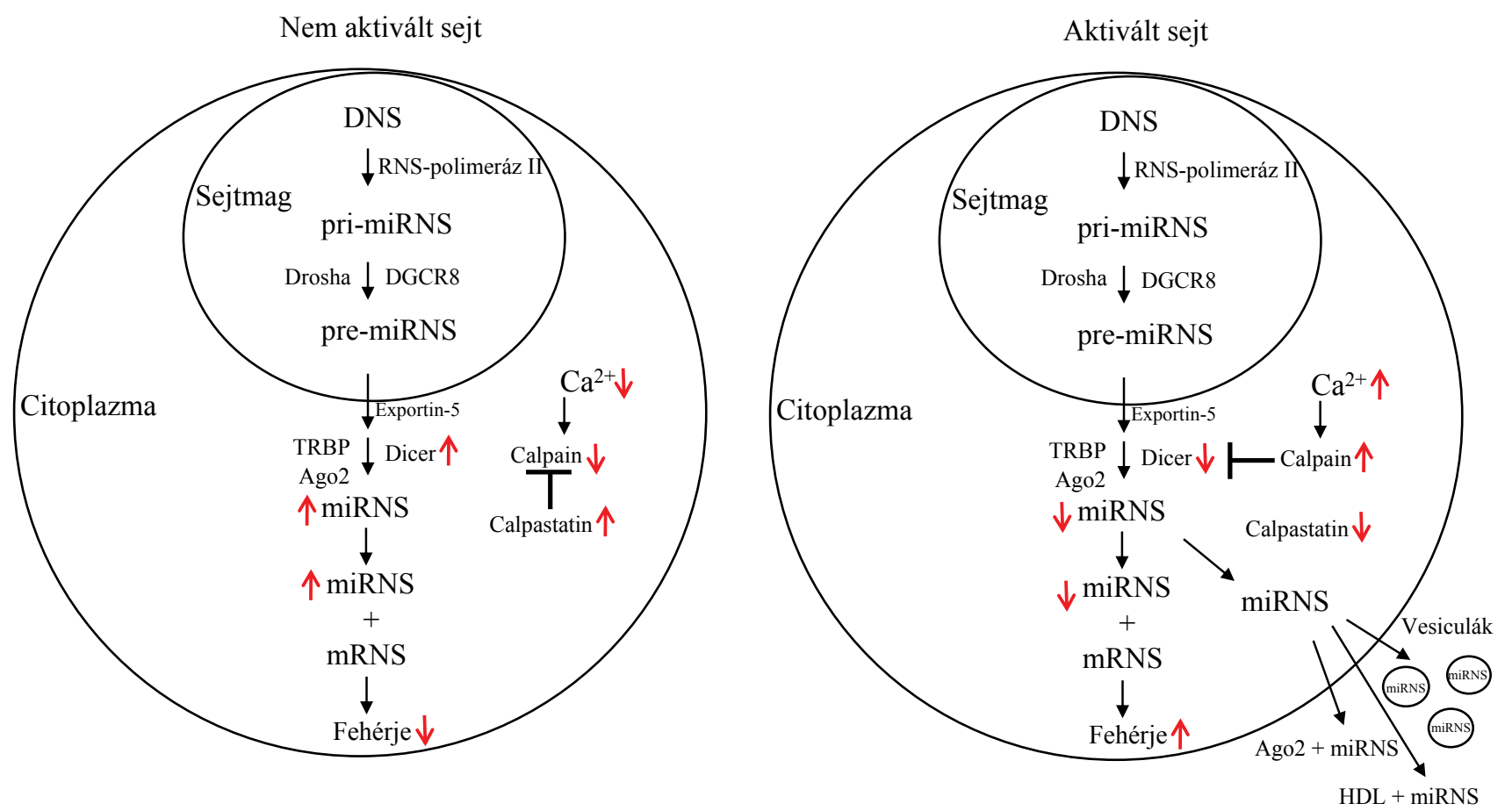

1. ábra

Nem aktivált és aktivált sejtben lejátszódó miRNS-érési folyamat, az azt befolyásoló legfontosabb enzimekkel és lehetséges miRNS-transzport-folya-
matokkal

\section{A miRNS-ek jelenléte a vérlemezkékben}

Sokan sokáig kételkedve fogadták, hogy a sejtmaggal nem rendelkező kering” „megakaryocyta-sejtdarabok” a 8-12 napos átlagélettartamukkal hordozhatnak-e egyáltalán funkcionális RNS-molekulákat, és ezáltal képesek lehetnek-e akár fehérjeszintézisre is. A thrombocyták érésük, majd a megakaryocytákról való lefúződésük során számos olyan sejtalkotóhoz (például riboszómák, endoplazmatikus reticulum, enzimek [például Dicer], továbbá mRNS-ek [13] és miRNS-ek [14]) jutnak, melyek birtokában képesek lehetnek de novo fehérjeexpresszióra bizonyos stimulusok hatására [15]. Mivel az mRNS-ek szintézisére viszont nincs lehetőség a vérlemezkékben, úgy tünik, hogy a pre-mRNS „splicing”-nak [16], illetve a miRNS-ek múködésének így jóval nagyobb szerep jutott, mint más sejtekben [14]. A vérlemezkékben relatíve nagyobb a miRNS/össz-RNS arány a fehérvérsejtekhez képest, ami szintén alátámasztja azt az elképzelést, hogy minél több érett funkcionális miRNS keletkezik [17]. Jelenleg több mint 500 thrombocyta-miRNS-t azonosítottak, amelyek nemcsak a vérlemezke-aktivációt elősegítő, de az azt megakadályozó fehérjék expresszióját is képesek befolyásolni, így kontrollálva egészséges körülmények között a felesleges vagy túlzott sejtaktivációt $[17,18]$. Ebből az is következik, hogy a vérlemezkék miRNS-profil-változása akut, illetve krónikus stimulus hatására jelentősen befolyásolhatja a thrombocytareaktivitás mértékét [18].
A több száz vérlemezke-miRNS közül körülbelül 1015 az átlagosnál nagyobb mennyiségben expresszálódik, így feltehetôen markánsabb szerepet töltenek be a thrombocytafunkció kontrollálásában [18]. Attól függő"en, hogy milyen metodikával, milyen egészségi állapotban lévő kontrollszemélyektôl, milyen típusú thrombocytamintákból (például friss vérminta vagy vérlemezkekoncentrátum) történt ennek korábban a meghatározása, némi eltérés azért megfigyelhetô az irodalomban erre vonatkozólag: míg Landry és mtsai a miR-142-t [14], addig mások a miR-223-at találták a legmagasabb expressziójú miRNS-nek [19]. A 10 legtöbb thrombocyta-miRNS közé tartozik még a miR-126, a let-7, a miR-103, a miR-185, a miR-199, a miR-21, a miR-26 és a miR-140 [13, 17, 19].

\section{A thrombocyta-miR NS-ek és a mRNS-ek szabályozásának általános aspektusai}

Az elmúlt néhány évben több olyan celluláris mechanizmus került leírásra, amelyek szabályozzák a miRNS-ek, valamint a cél-mRNS-ek expresszióját és múködését a thrombocytafunkcióban. Nem aktivált vérlemezkékben a miRNS-ek a RISC-en belül az Ago2 fehérjéhez kötődve megakadályozzák számos aktivációfüggő fehérje szintézisét [20]. Ugyanakkor trombinaktiváció hatására az mRNS leválik erról a komplexről, ami elősegíti az általa kódolt fehérje szintézisét, például a SERPINEl mRNS szabaddá válása a PAIl (plasminogen activator inhibi- 
tor-1) termelődéséhez vezet az aktivált vérlemezkékben [20]. Fontos szabályozó tényezőnek bizonyult a miRNS-ek éréséért felelős Dicer enzim aktivitásának szintje [21]. Eddigi klinikai és in vitro kísérletek eredményei alapján úgy tûnik, hogy akut vérlemezke-aktiváció esetén átmenetileg emelkedik számos miRNS expressziója a nem aktivált állapothoz képest elsősorban a fokozott Dicer-aktivitás miatt (például stroke akut fázisában vagy in vitro vérlemezke-aktiválás után), míg tartós vérlemezkestimuláció során, például diabetesben, csökkent a Dicerszint, ami számos érett miRNS alacsonyabb expressziójával járt együtt $[21,22]$. A Dicer alulmúködésének következményeit alátámasztják azok az állatkísérletes eredmények is, melyek a Dicerl-deficiens egerekben a vérlemezkék fibrinogén $\left(\alpha_{\text {IIb }} \beta_{3}\right)$-receptor-szintjét és így az in vivo thrombocytafunkciót is fokozottabbnak mutatták, mint a vad típusú állatokban [23].

A vérlemezkék miRNS/mRNS profilváltozásának egy másik oka lehet, hogy már a csontvelőben a megakaryocyták szintjén bekövetkezik az RNS-expressziók változása, és az újonnan lefüződött thrombocyták már megváltozott összetételü RNS-tartalmat kapnak. Erre igazolt példa krónikus gyulladásos környezetben az interferon- $\alpha$ hatására megváltozott génexpressziójú megakaryocyták és vérlemezkék megjelenése szisztémás lupus erythematosusban [24]. Hasonló következménnyel járhat diabetes mellitusban a hyperglycaemia megakaryocytákra kifejtett direkt hatása is (lásd később) [22, 25]. A fenti körülmények között olyan megváltozott miRNS- és mRNS-expresszióval bíró thrombocyták funkcionálhatnak a keringésben, amelyek hozzájárulnak az abnormális vérlemezke-múködés kialakulásához és annak számos szövődményéhez számos kórképben [13-15, 17, 18, 21, 22].

\section{Néhány miR NS validált célfehérjéje a thrombocytaaktiváció szabályozásában}

Néhány thrombocyta-miRNS-ról már sikerült igazolni a cél-mRNS-ével való interakcióját és annak közvetlen celluláris hatását. Elsóként a miR-223-ról mutatták ki, hogy a vérlemezke-funkció egyik legfontosabb szabályozó receptorának, a P2Y12-nek az ADP-receptor-expresszióját szabályozza [14]; azóta ezt a receptort összefüggésbe hozták a miR-126-tal is [26]. Az utóbbi miRNS emellett képes az ADAM9 (disintegrin and metalloproteinase domain-containing protein 9) fehérje expresszióját is gátolni, ami a vérlemezkék I. típusú kollagénhez való adhézióját képes megakadályozni [26]. A miR-223 a P2Y12-receptor mellett regulálja a thrombocyta $\beta 1$ integrin, kidlin-3 és FXIII-as véralvadási faktor A-alegységének (FXIIIA) expresszióját is, ami magyarázatot adhat a miR-223-depletált egerekben tapasztalt fokozott vérlemezke-aktivációra [21]. A vérlemezke-szekréciót koordináló egyik fehérje, a VAMP8 (vesicle-associated microtubule protein 8 ) expresszióját a miR-96 befolyásolta: megnőtt vérlemezke-funkcióban emelkedett VAMP8-mRNS-szintet és csökkent miR-96-expressziót
1. táblázat $\mid$ A thrombocytafehérjék expresszióját szabályozó celluláris miRNS-ek

\begin{tabular}{lll}
\hline miRNS & $\begin{array}{l}\text { A thrombocyta-fehérjeexpresszióban és } \\
\text {-funkcióban betöltött szerep }\end{array}$ & Irodalom \\
\hline miR-223 & $\begin{array}{l}\text { P2Y12-receptor-, ADAM9-, } \beta 1 \text {-integrin- }, \\
\text { FXIII-A-, kidlin-3-expresszió, ADP } \\
\text { indukálta vérlemezke-aktiváció, adhézió }\end{array}$ & {$[13,21$,} \\
\hline miR-96 & VAMP8-expresszió, thrombocytaszekréció & {$[27]$} \\
\hline miR-326 & $\alpha_{\text {IIb }} \beta_{3}$-receptor-expresszió & {$[23]$} \\
\hline miR-128 & $\alpha_{\text {IIb }} \beta_{3}$-receptor-expresszió & {$[23]$} \\
\hline miR-331 & $\alpha_{\text {IIb }} \beta_{3}$-receptor-expresszió & {$[23]$} \\
\hline miR-500 & $\alpha_{\text {IIb }} \beta_{3}$-receptor-expresszió & {$[23]$} \\
\hline miR-130a & $\alpha_{\text {IIb } \beta_{3} \text {-receptor-expresszió }}$ & {$[28]$} \\
\hline miR-200b & $\begin{array}{l}\text { A cAMP-függó proteinkináz A 2b-alegysé- } \\
\text { gének expressziója (PRKAR2B), epinefrin }\end{array}$ & {$[18]$} \\
& indukálta vérlemezke-aktiváció & \\
\hline miR-495 & $\begin{array}{l}\text { Kelch-like protein 5 (KLHL5) expressziója, } \\
\text { shape change” }\end{array}$ & {$[18]$} \\
\hline miR-26b & SELP (P-selectin)-receptor-expresszió & {$[22]$} \\
\hline miR-140 & $\begin{array}{l}\text { SELP (P-selectin)-receptor-expresszió } \\
{[22]}\end{array}$ \\
\hline
\end{tabular}

figyeltek meg, ami hozzájárult a fokozott szekréció bekövetkezéséhez [27]. A miR-26b és a miR-140 a P-selectin (SELP) mRNS-szintjét befolyásolta megakaryocyta-sejtkultúrákban [22]. Végül az $\alpha_{\mathrm{II}} \beta_{3}$-fibrinogénreceptort kódoló mRNS szintjét öt különböző miRNS is regulálja (miR-326, miR-128, miR-331, miR-500 [23] és miR-130a [28]. A miR-200b a cAMP-függő proteinkináz A 2b-alegységének kifejeződését szabályozza (PRKAR2B, cAMP-dependent protein kinase type II-beta regulatory subunit), amely az epinefrin indukálta vérlemezke-aktiváció mértékét befolyásolhatja, tehát a miR-200b felelós lehet a vérlemezkék alacsony aktivációs állapotának fenntartásáért [18]. Hasonló funkciót tölt be a miR-495 az úgynevezett Kelch-like protein 5 (KLHL5) represszálásával, mely fehérje a cytoskeletalis organizációban vesz részt, így járulva hozzá a thrombocyta-alakváltozás („shape change”) bekövetkezéséhez a vérlemezkeaktiváció korai szakaszában [18]. Az 1. táblázat összefoglalja azon thrombocyta-miRNS-eket, amelyeknek már igazolt a célfehérjéjük, valamint a vérlemezkefunkcióban betöltött szerepük.

\section{A miRNS-ek intercelluláris transzportmechanizmusai és azok jelentôsége}

A miRNS-ek nemcsak a saját, hanem - kijutva az anyasejtből - más környező sejtek múködését is befolyásolhatják úgynevezett RNS-transzfer révén. Napjainkban a hormonok, növekedési faktorok, chemokinek és citokinek mellett a miRNS-ekről is beigazolódott, hogy a sejtek közötti kommunikáció egyik fontos megnyilvánulási formáját képviselik. Ez az „információáramlás” egyrészt sejtnekrózis alkalmával valósul meg, amikor a miRNS-ek 
a sejtekból kiszabadulva HDL-hez (high density lipoprotein) vagy Ago2 ribonukleoproteinkomplexhez kötött formában szállítódnak tovább [4, 29]. Ugyanakkor aktív celluláris folyamat részeként exoszómákba, mikropartikulákba és apoptotikus testekbe csomagolva, leginkább thrombocytaeredetû mikropartikulákban is transzferálódhatnak [4] (1. ábra). A gyulladásos és thromboticus folyamatokat is elősegítő vérlemezke-eredetû mikropartikulák interakcióba léphetnek többek között az endothelsejtekkel [30, 31] és a makrofágokkal [32]. Az extracelluláris miRNS-ek egyik fó forrása maguk a vérlemezkék, amelyek a miRNS-ek átadása révén képesek befolyásolni más sejtek múködését, így a miR-320b az endothelsejtek ICAMI (intracellular adhesion molecule1)-expresszióját modulálhatja [30]. A thrombocytaeredetú mikropartikulák a miR-223-mal két endothelsejt célfehérje-mRNS-szintjét is befolyásolni tudták (FBXW7, onco-suppressor protein és EFNAl, glycosylphosphatidyl inositol-anchored receptor tyrosine kinase ligand) [31]. Néhány évvel később ugyanez a kutatócsoport igazolta a vérlemezke-mikropartikulákban szállított miR126 bejutását a humán makrofágokba, ami jelentősen csökkentette a CCL4 (cytokines/chemokines chemokine C-C motif ligand 4), a CSFl (colony stimulating factor 1) és a TNF (tumornekrózis-faktor) mRNS-szintjét és ezáltal ezeknek a citokineknek a szekrécióját, továbbá fokozta a makrofágok fagocytafunkcióját [32].

\section{Megváltozott thrombocyta- miRNS-expressziók 2-es típusú diabetes mellitusban}

Diabetes mellitusban az inzulinrezisztencia és a Langerhans-sejtek fokozatos kimerülése miatt gyakran kialakuló hyperglycaemia fokozatosan emeli a keringő vérlemezkék aktivációs állapotát, aminek következtében akár ki- sebb stimulus hatására is könnyen aktiválódhatnak [33]. A cukorbetegséghez társuló krónikus gyulladásos folyamatok, az endothelsejt-diszfunkció és az ezek talaján nagyobb valószínúséggel bekövetkező cardiovascularis komplikációk kialakulásáért jelentős mértékben a reaktív thrombocyták felelősek [33]. A thrombocytaaktiválódási folyamatok megelőzésével vagy gátlásával ugyanakkor jelentősen csökkenthetők a betegség morbiditási és mortalitási mutatói [33].

A thrombocyta-miRNS-ek létének igazolása [14] óta egyre több figyelem irányul arra, hogy ezeknek a nem kódoló RNS-eknek az expressziója hogyan változik, és vajon milyen szerepet tölthetnek be a különböző kórképekben, így a diabetes mellitushoz társult atherothromboticus folyamatokban. Csökkent thrombocytaés plazma-miR-223, -miR-126, -miR-26b, -miR-140 és -miR-146a-szintet mutattak ki hyperglycaemiában szenvedő diabeteses betegekben [22, 34, 35], ami összefüggésbe hozható az emelkedett P2Y12-receptor (mRNS)expresszióval, és ezen receptor abnormális funkciójával $[13,22,25]$, a nagyobb P-selectin-pozitivitással [22] és mindezáltal a fokozott vérlemezke-aggregációs készséggel [21]. A miRNS-ek megváltozott szintje hatással lehet a vérlemezke-funkciót gátló kezelés hatékonyságára is: a tartósan csökkent miR-223-expresszió a kezelés ellenére magas thrombocytareaktivitást és így kevésbé hatékony kezelést okozhat [36]. A diabetesesek thrombocytamintáiban kimutatott csökkent miR-223 és az előzőekben bemutatott célfehérjéi expressziójának eltérése szintén meghatározza az abnormális vérlemezke-funkciót [21]. Döntően a thrombocytákból kiszabaduló miR-197 és miR-2l csökkent szintjét mutatták ki diabeteses betegek plazmamintáiban egészséges kontrollokéival szemben [34].

A keringő aktivált vérlemezkékben megfigyelt miRNS-expresszió-eltérések hátterében jelentős részben a

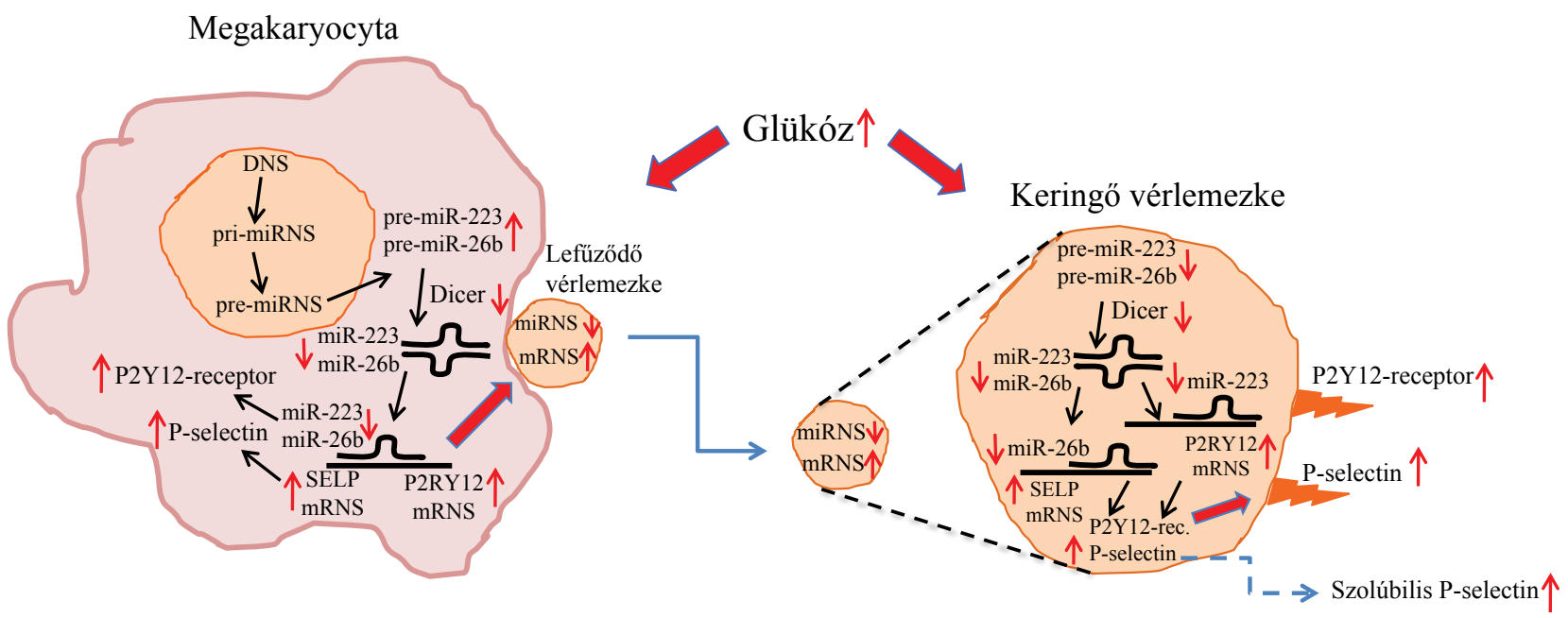

2. ábra $\quad$ Diabetes mellitusban a hyperglycaemia miatt bekövetkező bizonyos megakaryocyta- és thrombocyta-miRNS- és -mRNS-expresszió-eltérések, illetve azok funkcionális következményei

mRNs = hírvivő RNS; miRNS = mikro-RNS 
hyperglycaemia indukálta csökkent Dicer-aktivitás áll [21] (2. ábra). Az alacsony Dicer-aktivitás az emelkedett intracelluláris kalciumion-koncentráció által tartósan aktivált calpain 1/2 Dicert hasító múködésével van összefüggésben, ami a pre-miRNS-ek érését blokkolja [21]. A calpain $1 / 2$ in vitro gátlásával (calpeptin) ugyanakkor fenntartható a Dicer enzimaktivitása, ezáltal visszaállítható a miRNS-expresszió a hyperglycaemiás megakaryocytákban [22], míg a calpaininhibíciós kezelés a diabeteses egerekben stabilizálta a vérlemezkék fehérjeexpresszióját, valamint a thrombocytafunkciót [37].

$\mathrm{Az}$ abnormális metabolikus körülmények vérlemezkeaktiváló hatása mellett a hyperglycaemia megakaryocytákra kifejtett hatása is igazolható volt $[22,25]$ (2. ábra). Megakaryocyta-sejttenyészetekben munkacsoportunk is kimutatta korábban, hogy magas glükózkoncentráció mellett - a diabeteses vérlemezkékhez hasonlóan - csökkent egyes miRNS-ek szintje (például miR-223, miR26b) [22], és ez azt okozhatja, hogy megváltozott RNStartalmú thrombocyták képződjenek, melyek a keringésben már könnyebben aktiválódhatnak (2. ábra). Magához a megakaryocytapoesishez és thrombopoesishez is számos miRNS összehangolt múködése szükséges. A megakaryocyták differenciációja és proliferációja során csökken a miR-155 szintje [38], míg a miR-223 [39] emelkedett expressziója mutatható ki. Diabetes mellitusban a vérlemezkék patológiás funkciója mellett az endothelsejtek, a vascularis simaizomsejtek, a szívizomsejtek és a metabolikus folyamatok megváltozott múködésének hátterében is számtalan miRNS eltérése állhat, amire a jelen közlemény keretein belül nincs lehetőség kitérni.

\section{A thrombocyta-miRNS-expresszió- eltérések jelentősége szeptikus körülmények között}

\section{A vérlemezkék abnormális aktiválódása szepszisben}

A szepszis nagyfokú sejtaktivációval együtt járó gyulladásos válaszreakció, melynek hátterében valamilyen infekció áll. A kezdeti szisztémás gyulladásos reakciót több szervrendszer elégtelen múködése követheti: ez akár szeptikus sokkba progrediálhat, amelynek mortalitási mutatói napjainkban még mindig körülbelül 30-40\%-ra tehetők. A szepszis során felszabaduló gyulladásos citokinek (például TNF $\alpha$, különböző interleukinok stb.), illetve a baktériumok vagy azok (sejtfal)komponenseinek (LPS vagy PGN [peptidoglycane]) hatására aktiválódhatnak a thrombocyták [40]. A legfontosabb receptorcsalád, amely ezekben az interakciókban részt vesz, a TLR-k (Toll-szerú receptorok), amelyekból több típus (TLRl, -2, -4, -6) megtalálható a thrombocyták felszínén, illetve a vérlemezkéken belül (TLR3, -7, -9), és többek között az NF- $\kappa$ B útvonal aktiválódásához vezetnek [40]. Ezek közül a TLR4 receptor a szolúbilis CDl4 és az LBP (lipoproteinkötő fehérje) közremúködésével a Gram-negatív-baktérium-eredetú LPS-t, a TLR2 pedig a Gram-pozitív baktériumok lipoprotein komponenseit (PGN) köti meg, és ezen keresztül vérlemezke-aktiváció indukálódik [40]. A TLR2 mediálta aktiváció következményeként (például B-csoportú Streptococcus-baktérium, szintetikus TLR2-agonista $\operatorname{Pam}_{3} \mathrm{CSK} 4$ stb.) vérlemezkeaggregáció, -szekréció és fokozott CD40L-, valamint Pselectin-expresszió következik be [41], míg a TLR4-en keresztüli stimuláció mérsékelten emelkedett CD63-, de változatlan P-selectin-expressziót, csökkent RANTES(regulated upon activation, normal T-cell expressed, and presumably secreted) felszabadulást, ugyanakkor fokozott foszfatildil-szerin expozíciót okozott [42]. Az LPS vagy annak rövidebb láncú formája (Re-LPS) bár önmagában nem tudott thrombocytaaggregációt generálni, képes volt in vitro pontencírozni a klasszikus vérlemezke-agonista (például TRAP [trombinreceptor-aktiváló peptid]) aktiváló hatását [11]. Szeptikus betegek gyakran mutatnak fokozott vérlemezke-aktivációt, amely súlyos thrombocytopeniához vezethet, részben a tüdőbe szekvesztrálódott aktiválódott thrombocyták miatt, amit állatkísérletekben is igazoltak [43], részben a baktériumok indukálta vérlemezke-apoptózis miatt [44]. A vérlemezkék mellett a megakaryocyták is expresszálnak számos TLR-t, így a TLR4-et is, amelynek expressziója a megakaryocyták érése során - a növekvő CD41/CD61 pozitivitás mellett - fokozatosan nőtt [43]. Szepszis során a gyulladásos citokinekkel együtt a baktériumok is bejuthatnak a csontvelőbe, gátolhatják a thrombopoesist [45], és a TLR2-n keresztül jelentős mértékben modulálhatják is a megakaryocyták génexpressziós szabályozását [46].

\section{Szepszis indukálta RNS-expresszió-páltozások thrombocytákban és megakaryocytákban}

Súlyos gyulladásos és fertózéses állapotban olyan transzkripciós és poszttranszkripciós folyamatok indukálódhatnak már a megakaryocytákban, melyek által megváltozott RNS-tartalmú és abnormális funkciójú vérlemezkék termelődnek [14]. Erre az egyik első bizonyíték az volt, hogy szeptikus egerek megakaryocytasejtjei már 24 óra után olyan lymphotoxicus, emelkedett intracelluláris granzyme B-expressziót mutató thrombocytákat termeltek, amelyek fokozták a szepszishez társuló mortalitást az állatokban [47].

Az elmúlt években néhány olyan eredmény is napvilágot látott, amelyek a szeptikus állapot okozta megváltozott vérlemezke-fenotípusról szóltak a fehérjeszintézist előkészítő, majd az azt reguláló RNS-expresszió-változások igazolásával. Emelkedett szövetifaktor-expresszióról számoltak be in vitro körülmények között az LPS hatására bekövetkező szöveti faktor pre-mRNS-,splicing”jával [48]. Továbbá alacsony LPS-koncentráció jelenlétében a vérlemezkék az ILl $\beta$ transzlációjára is képesek voltak egy másik tanulmány szerint [49]. 
Ezen túlmenően a kisfokú endotoxaemia akár fokozhatja is a vérlemezke- „turnover”-t, ami nagyobb menynyiségü, fiatal, sokkal reaktívabb vérlemezkék termelödéséhez vezethet [50]. Ezek a fiatal(abb) thrombocyták nagyobb és megváltozott RNS-tartalommal bírnak, miáltal nagyobb eséllyel képesek akár fehérjeszintézisre, továbbá vérrögképződésben részt venni, idősebb társaikkal szemben [50]. Mindezek alapján a thrombocyták és a megakaryocyták egyaránt nagymértékben ki vannak téve a szepszis infektív és inflammatoricus mediátorainak [51]. Ugyanakkor kevés információ áll jelenleg rendelkezésünkre, hogy pontosan mely thrombocyta-miRNS-ek mely célfehérjék termelődését tudják fokozni ebben a kórképben, illetve az egyes miRNS-ek szintje milyen egyéb mechanizmussal kerül szabályozásra.

Eddig egyetlen közlemény vizsgálta a celluláris és az extracelluláris miRNS-ek expresszióját szeptikus betegek mintáiban [52]. Reithmair és mtsai izolált exoszómákban, szérummintákban, valamint a vér alakos elemeinek együttes mintáiban analizálták a különböző miRNS-eket [52]. Azt tapasztalták, hogy a celluláris miR-199b jelentősen csökkent mind szepszisben, mind szeptikus sokkban, ami korán jelzi előre a kórkép kialakulását. A csökkent miR-26b a szérumban, míg az emelkedett miR-125b az exoszómákban volt egyedülállóan eltérő, ezért úgy tünik, hogy a szepszishez köthető miRNS-eltérések „sejtkompartment-specifikusak” [52]. Ezzel párhuzamosan több keringő miRNS-t is vizsgáltak szepszisben, amelyek jó biomarkernek bizonyultak a betegség igazolásában vagy a komplikációk előrejelzésében, ilyen a szérumban mért csökkent miR-146a és miR-223 [53]. A szérum-miR-122 jól korrelált a koagulációs zavarok kialakulásával, miután sokkal magasabb volt a szintje azokban a betegekben, akikben disszeminált intravascularis koaguláció (DIC) is kialakult [54].

A thrombocyták miRNS-profil-változásával szepszisben eddig kevesen foglalkoztak. Saját eredményeink alapján a miR-223 és a miR-26b szintje jelentősen alacsonyabb volt a fehérvérsejt-depletált vérlemezkemintákban az emelkedett miR-155 jelenlétében, és mindez emelkedett P2RY12-, valamint SELP-mRNS-szintet okozott a felszíni és szolúbilis P-selectin-értékekkel kimutatott vérlemezke-aktivációban [55]. A let-7 miRNScsalád körülbelül a felét teszi ki az összes vérlemezke-miRNS-nek [17]. A let-7 a TLR7-expressziót regulálja a neuronokban [56], ami felveti annak lehetőségét, hogy a vérlemezkékben is hasonló szerepet játszhat, de ez egyelöre nem bizonyított.

Korábban számos gyulladásos celluláris folyamatot hoztak összefüggésbe a fokozott calpainaktivitással. A calpainspecifikus inhibitorral (calpastatin) történő kezelés egy szeptikus egérmodellben csökkentette a prokoaguláns mikropartikulák mennyiségét és a trombingenerációt, ami a DIC súlyosságát is jelentősen mérsékelte [57]. Továbbra is kérdéses, hogy a calpain által befolyásolt Dicer enzim aktivitása, ami az általános thrombocytafunkció egyik fontos indirekt szabályozójának tünik
[23], hogyan változik a szeptikus körülményeknek kitett vérlemezkékben és megakaryocytákban. Ennek felderítésére további vizsgálatok szükségesek.

\section{Következtetések}

Az elmúlt 10 évben, amióta ismertté vált, hogy a humán vérlemezkék is hordoznak és adott esetben más sejteknek át is adhatnak funkcionális miRNS-eket, a tudományos érdeklődés egyre nagyobb részben a megváltozott celluláris és extracelluláris miRNS-expressziók kimutatása, részben az in vitro körülmények között igazolható funkciójuk felé fordult. Több miRNS-nek már bizonyított a finomszabályozó szerepe: nemcsak a thrombocytákban, hanem például az endothelsejtekben is befolyásolják az inflammatoricus folyamatok lejátszódását [58]. Új laboratóriumi biomarkerként a keringő miRNS-ek fontos szerepet játszhatnak a közeljövőben nemcsak a vérlemezke-aktivációval együtt járó betegségek vagy azok komplikációinak előrejelzésében $[22,34,35,53$, 54], hanem daganatos kórképek kivizsgálásában [59] vagy egyéb kórképek nem invazív diagnosztikájában [60].

Anyagi támogatás: A tanulmány az Emberi Erőforrások Minisztériuma ÚNKP-17-3. kódszámú Új Nemzeti Kiválóság Programjának támogatásával készült (Fejes Zsolt).

Szerzői munkamegosztás: Az összefoglaló cikk megírásában minden szerző részt vett, és a végleges változatát valamennyi szerző elolvasta és jóváhagyta.

Érdekeltségek: A szerzőknek nincsenek érdekeltségeik.

\section{Irodalom}

[1] Bartel DP. MicroRNAs: genomics biogenesis, mechanism and function. Cell 2004; 116: 281-297.

[2] Wiemer EA. The role of microRNAs in cancer: no small matter. Eur J Cancer 2007; 43: 1529-1444.

[3] Weber JA, Baxter DH, Zhang S, et al. The microRNA spectrum in 12 body fluids. Clin Chem. 2010; 56: 1733-1741.

[4] Turchinovich A, Tonevitsky AG, Burwinkel B. Extracellular miRNA: a collision of two paradigms. Trends Biochem Sci. 2016; 41: 883-892.

[5] Nomura S. Extracellular vesicles and blood diseases. Int J Hematol. 2017; 105: 392-405.

[6] Sunderland N, Skroblin P, Barwari T, et al. MicroRNA biomarkers and platelet reactivity: the clot thickens. Circ Res. 2017; 120: $418-435$

[7] Ruggeri ZM. Platelets in atherothrombosis. Nat Med. 2002; 8: 1227-1234.

[8] Koupenova M, Clancy L, Corkrey HA, et al. Circulating platelets as mediators of immunity, inflammation, and thrombosis. Circ Res. 2018; 122: 337-351.

[9] Nagy B Jr, Csongrádi E, Bhattoa HP, et al. Investigation of Thr715Pro P-selectin gene polymorphism and soluble P-selectin levels in type 2 diabetes mellitus. Thromb Haemost. 2007; 98 : 186-191. 
[10] Nagy B Jr, Jin J, Ashby B, et al. Contribution of the P2Y12 receptor mediated pathway to platelet hyperreactivity in hypercholesterolemia. J Thromb Haemost. 2011; 9: 810-819.

[11] Kappelmayer J, Beke Debreceni I, Vida A, et al. Distinct effects of Re- and S-forms of LPS on modulating platelet activation. J Thromb Haemost. 2013; 11: 775-778.

[12] Kappelmayer J, Nagy B Jr, Miszti-Blasius K, et al. The emerging value of P-selectin as a disease marker. Clin Chem Lab Med. 2004; 42: 475-486.

[13] Rondina MT, Weyrich AS. Regulation of the genetic code in megakaryocytes and platelets. J Thromb Haemost. 2015; 13(Suppl 1): S26-S32.

[14] Landry P, Plante I, Ouellet DL, et al. Existence of a microRNA pathway in anucleate platelets. Nat Struct Mol Biol. 2009; 16: 961-966.

[15] Zimmerman GA, Weyrich AS. Signal-dependent protein synthesis by activated platelets: new pathways to altered phenotype and function. Arterioscler Thromb Vasc Biol. 2008; 28: 17-24.

[16] Denis MM, Tolley ND, Buntin M, et al. Escaping the nuclear confines: signal-dependent pre-mRNA splicing in anucleate platelets. Cell 2005; 122: 379-391.

[17] Plé H, Landry P, Benham A, et al. The repertoire and features of human platelet microRNAs. PLoS ONE 2012; 7: e50746.

[18] Nagalla S, Shaw C, Kong X, et al. Platelet microRNA-mRNA coexpression profiles correlate with platelet reactivity. Blood 2011; 117: 5189-5197.

[19] Simon LM, Edelstein LC, Nagalla S, et al. Human platelet microRNA-mRNA networks associated with age and gender revealed by integrated plateletomics. Blood 2014; 123: e37-e45.

[20] Corduan A, Plé H, Laffont B, et al. Dissociation of SERPINE] mRNA from the translational repressor proteins Ago2 and TIA1 upon platelet activation. Thromb Haemost. 2015; 113: 10461059.

[21] Elgheznawy A, Shi L, Hu J, et al. Dicer cleavage by calpain determines platelet microRNA levels and function in diabetes. Circ Res. 2015; 117: 157-165.

[22] Fejes Z, Póliska S, Czimmerer Z, et al. Hyperglycemia suppresses microRNA expression in platelets to increase P2RY12 and SELP levels in type 2 diabetes mellitus. Thromb Haemost. 2017; 117: 529-542.

[23] Rowley JW, Chappaz S, Corduan A, et al. Dicerl-mediated miRNA processing shapes the mRNA profile and function of murine platelets. Blood 2016; 127: 1743-1751.

[24] Lood C, Amisten S, Gullstrand B, et al. Platelet transcriptional profile and protein expression in patients with systemic lupus erythematosus: up-regulation of the type I interferon system is strongly associated with vascular disease. Blood 2010; 116: 1951-1957.

[25] Hu L, Chang L, Zhang Y, et al. Platelets express activated P2 $\mathrm{Y}_{12}$ receptor in patients with diabetes mellitus. Circulation 2017; 136: 817-833.

[26] Kaudewitz D, Skroblin P, Bender LH, et al. Association of microRNAs and YRNAs with platelet function. Circ Res. 2016; 118: 420-432.

[27] Kondkar AA, Bray MS, Leal SM, et al. VAMP8/endobrevin is overexpressed in hyperreactive human platelets: suggested role for platelet microRNA. J Thromb Haemost. 2010; 8: 369-378.

[28] Garzon R, Pichiorri F, Palumbo T, et al. MicroRNA fingerprints during human megakaryocytopoiesis. Proc Natl Acad Sci USA 2006; 103: 5078-5083.

[29] Arroyo JD, Chevillet JR, Kroh EM, et al. Argonaute2 complexes carry a population of circulating microRNAs independent of vesicles in human plasma. Proc Natl Acad Sci USA 2011; 108 5003-5008.

[30] Gidlöf $O$, van der Brug $M$, Ohman J, et al. Platelets activated during myocardial infarction release functional miRNA, which can be taken up by endothelial cells and regulate ICAMl expression. Blood 2013; 121: 3908-3917.
[31] Laffont B, Corduan A, Plé H, et al. Activated platelets can de liver mRNA regulatory Ago2*microRNA complexes to endothelial cells via microparticles. Blood 2013; 122: 253-261.

[32] Laffont B, Corduan A, Rousseau M, et al. Platelet microparticles reprogram macrophage gene expression and function. Thromb Haemost. 2016; 115: 311-323.

[33] Ferroni P, Basili S, Falco A, et al. Platelet activation in type 2 diabetes mellitus. J Thromb Haemost. 2004; 2: 1282-1291.

[34] Zampetaki A, Kiechl S, Drozdov I, et al. Plasma microRNA profiling reveals loss of endothelial miR-126 and other microRNAs in type 2 diabetes. Circ Res. 2010; 107: 810-817.

[35] Duan X, Zhan Q, Song B, et al. Detection of platelet microRNA expression in patients with diabetes mellitus with or without ischemic stroke. J Diabetes Complications 2014; 28: 705-710.

[36] Zhang YY, Zhou X, Ji WJ, et al. Decreased circulating microRNA-223 level predicts high on-treatment platelet reactivity in patients with troponin-negative non-ST elevation acute coronary syndrome. J Thromb Thrombolysis 2014; 38: 65-72.

[37] Randriamboavonjy V, Isaak J, Elgheznawy A, et al. Calpain inhibition stabilizes the platelet proteome and reactivity in diabetes. Blood 2012; 120: 415-423.

[38] Romania P, Lulli V, Pelosi E, et al. MicroRNA 155 modulates megakaryopoiesis at progenitor and precursor level by targeting Ets- 1 and Meisl transcription factors. Br J Haematol. 2008; 143: $570-580$.

[39] Felli N, Pedini F, Romania P, et al. MicroRNA 223-dependent expression of LMO2 regulates normal erythropoiesis. Haematologica 2009; 94: 479-486.

[40] Cognasse F, Nguyen KA, Damien P, et al. The inflammatory role of platelets via their TLRs and Siglec receptors. Front Immunol. 2015; 6: 83.

[41] Liu X, Liu H, Luo X, et al. Strains of Group B streptococci from septic patients induce platelet activation via Toll-like Receptor 2 . Clin Exp Pharmacol Physiol. 2017; 44: 335-343.

[42] Cognasse F, Hamzeh-Cognasse $\mathrm{H}$, Lafarge $\mathrm{S}$, et al. Toll-like receptor 4 ligand can differentially modulate the release of cytokines by human platelets. Br J Haematol. 2008; 141: 84-91.

[43] Andonegui G, Kerfoot SM, McNagny K, et al. Platelets express functional Toll-like receptor-4. Blood 2005; 106: 2417-2423.

[44] Kraemer BF, Campbell RA, Schwertz H, et al. Bacteria differentially induce degradation of $\mathrm{Bcl}-\mathrm{xL}$, a survival protein, by human platelets. Blood 2012; 120: 5014-5020.

[45] Wain J, Pham VB, Ha V, et al. Quantitation of bacteria in bone marrow from patients with typhoid fever: relationship between counts and clinical features. J Clin Microbiol. 2001; 39: 15711576.

[46] Beaulieu LM, Lin E, Morin KM, et al. Regulatory effects of TLR2 on megakaryocytic cell function. Blood 2011; 117: 59635974.

[47] Freishtat RJ, Natale J, Benton AS, et al. Sepsis alters the megakaryocyte-platelet transcriptional axis resulting in granzyme Bmediated lymphotoxicity. Am J Respir Crit Care Med. 2009; 179: $467-473$.

[48] Rondina MT, Schwertz H, Harris ES, et al. The septic milieu triggers expression of spliced tissue factor mRNA in human platelets. J Thromb Haemost. 2011; 9: 748-758.

[49] Shashkin PN, Brown GT, Ghosh A, et al. Lipopolysaccharide is a direct agonist for platelet RNA splicing. J Immunol. 2008; 181: 3495-3502.

[50] Harrison P, Goodall AH. "Message in the platelet" - more than just vestigial mRNA! Platelets 2008; 19: 395-404.

[51] Jayachandran M, Brunn GJ, Karnicki K, et al. In vivo effects of lipopolysaccharide and TLR4 on platelet production and activity: implications for thrombotic risk. J Appl Physiol (1985). 2007; 102: 429-433.

[52] Reithmair M, Buschmann D, Märte $M$, et al. Cellular and extracellular miRNAs are blood-compartment-specific diagnostic targets in sepsis. J Cell Mol Med. 2017; 21: 2403-2411. 
[53] Wang JF, Yu ML, Yu G, et al. Serum miR-146a and miR-223 as potential new biomarkers for sepsis. Biochem Biophys Res Commun. 2010; 394: 184-188.

[54] Wang HJ, Deng J, Wang JY, et al. Serum miR-122 levels are related to coagulation disorders in sepsis patients. Clin Chem Lab Med. 2014; 52: 927-933.

[55] Fejes Z, Orosz T, Póliska S, et al. Septic conditions modulate the level of miRNAs in platelets and megakaryocytes that may contribute to abnormal platelet reactivity. Res Pract Thromb Haemost. 2017; S1: 16.

[56] Lehmann SM, Krüger C, Park B, et al. An unconventional role for miRNA: let-7 activates Toll-like receptor 7 and causes neurodegeneration. Nat Neurosci. 2012; 15: 827-835.

[57] Zafrani L, Gerotziafas G, Byrnes C, et al. Calpastatin controls polymicrobial sepsis by limiting procoagulant microparticle release. Am J Respir Crit Care Med. 2012; 185: 744-755.
[58] Fejes Z, Czimmerer Z, Szük T, et al. Endothelial cell activation is attenuated by everolimus via transcriptional and post-transcriptional regulatory mechanisms after drug-eluting coronary stenting. PLoS ONE 2018; 13: e0197890.

[59] Decmann Á, Perge P, Nagy Z, et al. Circulating microRNAs in the diagnostics of endocrine neoplasms. [Keringő mikroRNS-ek az endokrin daganatok diagnosztikájában.] Orv Hetil. 2017; 158: 483-490. [Hungarian]

[60] Nagy B, Csanádi Z, Póka R. The importance of "free" nucleic acids in the non-invasive diagnostics. [A ,szabad” nukleinsavak jelentősége a noninvazív diagnosztikában.] Orv Hetil. 2016; 157: 1900-1909. [Hungarian]

(ifj. Nagy Béla dr., Debrecen, Nagyerdei krt. 98., 4032 e-mail: nagy.bela@med.unideb.hu)

\section{Innovatív megoldások a diagnosztikában}

Kórházi környezetben is hosszú évekig megbízhatóan működő technika és a precíz képmegjelenítés révén lehető legpontosabb diagnózis lehetőségének megteremtése - ezzel a céllal lépett nemrég piacra az LG Electronics klinikai és sebészeti monitoraival.

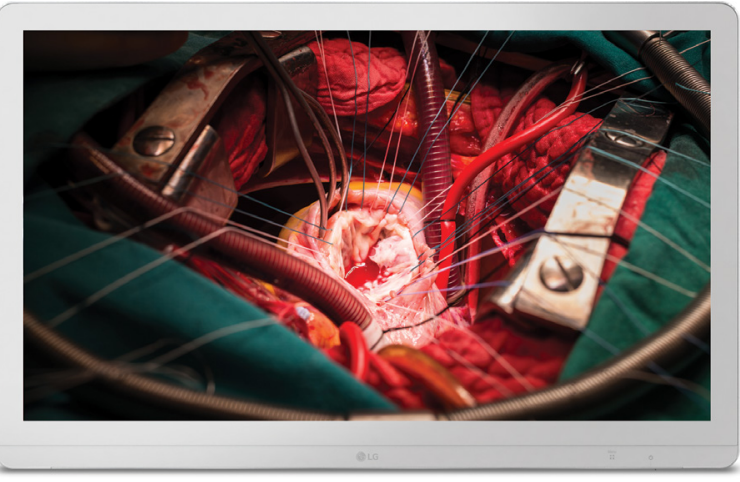

\section{Klinikai monitorok}

Az LG klinikai felhasználásra készült monitorai megfelelnek a DICOM Part 14 szabványnak, vagyis színmegjelenítésük és minőségük is összhangban van az amerikai elektronikai gyártók szövetsége és az Amerikai Radiológiai Testület szigorú iránymutatásaival. Az eszközök képmegjelenítése teljesen tiszta és torzításmentes, az LG emellett az intenzív használatból adódó teljesítményvesztés kiküszöbölésére is odafigyelt, és háttérvilágítás-stabilizáló technológiával látta el a monitorokat.

A termékekben többek közt olvasómód és egy ún. Flicker Safe funkció is található, előbbi a szemnek ártalmas kék fényt, utóbbi pedig a kép vibrálását szüri ki, így hosszabb idő után sem válik fárasztóvá a képernyő előtt végzett munka.

A 19 hüvelykes, 1,3 MP-es felbontású típus (19HK312C) két irányban is elfordítható, felülete pedig antimikrobiális tulajdonságú, így megfelel az ISO 22196 szabványnak. Képes az NTSC színtér 72 százalékának megjelenítésére, ami kifejezetten a szürkeárnyalatos röntgenfelvételek megtekintésében nyújt segítséget.

A 27 hüvelykes, $8 \mathrm{MP}$ felbontású monitor (27HJ712C) az sRGB színtér 99 százalékát képes megjeleníteni, a 178 fokos torzításmentes betekintési szögnek köszönhetően pedig egyszerre többen is kényelmesen nézhetik.

\section{Sebészeknek}

Az LG 27 hüvelykes, 8 MP felbontású, tökéletes színmegjelenítésre képes monitorját (27HJ7105) kifejezetten sebészeti beavatkozásokhoz fejlesztette ki. Ebben a készülékben az IPS képernyő-technológia felel a részletgazdag képmegjelenítésért, az sRGB színtér 115 százalékának megjelenítése mellett pedig a mélyvörös színspektrum összes tónusa látható. E kijelzőtechnológia a belső tükröződést meggátolva, a mütőtermi lámpák erős fénye mellett is tökéletes láthatóságot nyújt.

Ez a készülék is megfelel a DICOM Part 14 szabványnak, automata fényerőszabályozóval rendelkezik és a mütőben gyorsan zajló eseményeket követve mindent valós időben, elmosódásmentesen képes megjeleníteni. Az IP32 és IP35 védettséggel rendelkező eszköz ellenáll a műtét során esetlegesen rákerülő szennyeződéseknek, felülete pedig egyszerűen tisztítható.

Az LG klinikai és sebészeti monitorai már Magyarországon is elérhetők.

További információ: www.lg.com/hu 